ISBN 978-81-933894-6-1

4th International Conference on Business, Education, Law and Interdisciplinary Studies

(BELIS-17)

London (UK) June 29-30, 2017

\title{
The Effect of Security Risk on the Usage of Mobile Banking Apps in Jordan
}

\author{
Jawdat Al-Tarawneh, Anthony Gear, Amina Elshamly and Tamer Darwish \\ Business and Computing School, University of Gloucestershire, United Kingdom
}

\begin{abstract}
Mobile banking is an example of the recent boom of the mobile technology. Even though the penetration of other self-service technologies of banking channels (ATM, Telebanking and Internet banking), mobile banking has more significant effects on such markets. However, there are still some concerns to use the mobile banking apps because of some risks that might cause financial loss. Therefore, this paper will focus on the issues related to security risks and its effect upon the usage of mobile banking apps. This paper explore the effect of security risk on the adoption of mobile banking apps by Jordanian customers. Questionnaire has been distributed, the findings of an online survey with 416 respondents describe Jordanians' adoption of mobile banking apps. This online survey was shared over email and other social media channels. Results indicate that the factor of security risk significantly influencing the adoption of mobile banking.
\end{abstract}

Keywords: Security risk, Mobile banking, online banking, Jordan, usage.

\section{Introduction}

Mobile banking solutions first introduced to the Finnish customers in 1992. Banks provide their customers of alternatives to perform banking transactions and phones. Since that time, a new global trend of using mobile banking services have been created to use banking services through mobile devices [1] [29]. Banks in different countries are offering M-Banking technology to their customers, but despite the widespread adoption of mobile devices, such as smartphones and tablets, the adoption rate of mobile Banking is still low [12]. Electronic banking services launched in Jordan by 2002, since when Jordanian banks have been active in establishing internet Banking, and mobile banking services.

A limited number of previous academic studies have examined the role of the perceived security risk on the mobile banking in Jordan [13]. So, this paper explore the effect of security risk on the adoption of mobile banking apps by Jordanian customers. New technological solutions have changed how customers interact with their shopping, payments and banking. For example, customers have several alternatives when paying for their purchase such as paying by traditional (contact/contactless) credit card, online payment, or mobile devices, all of which are a result of the rapid development in innovations of banking and payment methods [2]. Recently, smartphones have become a key technological device and many activities have been penetrated in many countries by the use of smartphones and their applications [3] [29].

Such electronic banking solutions offer an effective delivery channels for traditional banking products, mobile banking is likely to have significant effects on markets [4]. This technology allows people to perform bank transactions anytime and anywhere [5]. In particular, the rapid growth in the use of smart phones has increased the need for mobile banking services, and requires service providers to include this innovative service with new sets of products, services and applications designed to expand their clients' access, improve customer loyalty, enhance operational efficiency, increase market share, and provide new jobs [6]. 
However, the lack of mobility in the use of internet banking became a main concern for users as they were only able to use local area networks (LAN) or WI-FI connections to access internet banking, in addition to which they needed to be on a personal computer (PC) such as a desktop or laptop to conduct their transactions. As a result, the banks found there was a need to enhance customer satisfaction by providing flexible services to customers whenever and wherever they wanted them [7]. Mobile banking attempted to solve these issues by enabling customers to be on the move and utilize their devices to perform the financial activities they need without the previous limitations associated with traditional banking or internet banking [8]. Mobile banking allows bank customers to perform banking services via their portable devices or smart phones, such as: inquiries only services such as (finding ATM locations and account management), or other financial transactions such as (paying bills, transferring money) as shown in table 1 [9].

Table 1: Mobile Banking Services.

\begin{tabular}{|c|c|}
\hline financial services & Inquiries only services \\
\hline Bill payments & Balance enquiry \\
\hline Peer-to-peer payments & Mini-bank statement \\
\hline Fund transfers & PIN change \\
\hline Remittance & Check book request \\
\hline Shopping and donations & Due alerts for payments \\
\hline Mobile balance top-up & Locate ATMs \\
\hline
\end{tabular}

As mentioned before, a limited number of previous academic studies has examined the effect of security risk on the adoption of mobile banking apps from the customers' perspective in Jordan. An investigation of this kind seeks to fill the research gap that was identified through the limited amount of research available on the topic when talking about mobile-context technology acceptance factors from the perspective of customers. The primary objective of this paper is to explore and understand the relation between the security risk and usage of mobile banking apps.

\section{Literature Review}

Banking sector in worldwide exerts huge efforts to provide their customers with a satisfied level of mobile banking services, but despite the widespread adoption of mobile devices, such as smartphones and tablets, the adoption rate of M-Banking is still low [10] [11] [12] [29]. There is many reason or barriers that affect the adoption of mobile banking and one of the most known factors that affect the usage of mobile banking is the Security risk. Security risk is mainly the risk that user's account information can be compromised and used in a manner which can cause some tangible or intangible damage/loss to the account holder.

Security risks occur when customers are worried that other can see their personal financial information without their consent and this concern creates security risk, which consecutively affect the adoption of mobile banking apps [13]. It has become a real challenge for banks to provide information security [13] [4] because users like to control all aspects of gathering information while using online services [10]. This issue has gained the attention of many researchers who have studied such kind of behavior. According to consumers security risk is often associated with the possibility of losing money. Surveys show that the adoption of mobile banking services is greatly influenced by security risk. The gap between the actual and perceived security of a technology is what affects the behaviour of people [28] [29].

Technology adoption means the acceptance of new innovations, techniques and tools in executing specific tasks, thus, the acceptance is an indication of an individual's readiness to perform a given behavior. [14], so there are many theories and models of technology acceptance. There are several dominant models of technology 
acceptance. UTAUT is a unified model that is formed from the integration of eight dominant models in the field: the theory of reasoned action [15], technology acceptance model [16], motivational model [17], the theory of planned behavior [14], the combined theory of planned behavior and technology acceptance model [18], model of personal computer use [19], diffusion of innovations theory [20], and social cognitive theory [21].

With regard to the literature review of banking services, the adoption of traditional banking services by customers is usually different than adoption of other online applications or software, as it is affected by the factor of transactional and security risk, which means the risk that the transaction executed by the bank customer does not take place as expected by the client [25]. It also represents the important concerns of customers; concerns that are usually related to the type of transaction performed and if it is transactional or nontransactional and also related to the amount of money they are going to send via their m-banking applications. Based on the aforementioned discussion, this paper tries to explain the relation between the security risk and the usage of the mobile banking usage by Jordanian customers.

\section{Methodology}

This paper is an exploratory study to explore and understand the factor of the security risk and its effect on the adoption of mobile banking by Jordanian customers. The method used a self-reported and anonymous online questionnaire using the Bristol online survey, (https://www.onlinesurveys.ac.uk). The survey's URL was distributed over the email and some Jordanian social media websites. The questionnaire consisted of three sections, including: Demographics, Actual use of mobile Banking apps, and views about the security of mobile banking apps, which were assessed on a 5-point Likert scale. There were also the following open-ended questions providing participants with the opportunity to comment and add views on the same page of the online survey:

- What are the main obstacles you find during the use of M-banking?

-Do you think the use of M-banking depends on the nature of the task you intend to do (transactional/nontransactional)?

- Do you recommend or not using mobile banking to your friends? Why?

- What would encourage you to use M-banking?

The respondents' comments assured the researcher that the language used was simple and clear; in addition, the questionnaire length was suitable and did not consume much of the respondents' time. There are two main factors in this paper the usage of mobile banking (dependent variable) plus the Security risk (Independent variable). Bothe factors have been measure by set of questionnaire items explains below:

\begin{tabular}{ll}
\hline Usage & -How frequent do you use mobile \\
banking app & \\
\hline & 1- I think that M-banking app has sufficient security features. \\
2-I would not feel secure by passing my sensitive information via the app of M-banking. \\
3-I believe my \\
bank information is well secured by the \\
Provider of M-banking app. \\
4-I think M-banking provider checks all \\
communications between the \\
App and me for protection from hacking or eavesdropping. \\
5- Only authorized users are able to access to secret information on M-banking app. \\
6- M-banking app ascertains the identity of user every single login. \\
7- The reports and news about M-banking fraud worry me about the security of M-banking.
\end{tabular}


This paper develop one hypothesis:

H1: The usage of M-banking applications by Jordanians will be affected negatively by security risk.

\section{Findings}

There were 416 respondents after two months of publish the survey link on social media and e-mail. Moreover, in order to make sure that all measurement items have an acceptable level of internal consistency reliability, an examination of Cronbach's alpha values was carried out and distributed using SPSS [26].Cronbach's alpha value exceeding 0.70 , as shown in table II, and it is highly recommended by [27]., was considered to be the threshold level to approve the measures' reliability This, in turn, demonstrated that the measures adopted were able to have an acceptable level of internal consistency and adequately satisfied the reliability criteria in purpose to design the main extended survey which will be shown in another article.

Table II: Cronbach's Alpha Results of the Pilot Study

\begin{tabular}{|l|c|c|}
\hline M-banking app Security risk (SR) & $\begin{array}{c}\text { N\# of } \\
\text { items }\end{array}$ & $\begin{array}{c}\text { Cronbach's } \\
\text { alpha }\end{array}$ \\
\hline The Overall questionnaire. & 7 & 0.86 \\
\hline
\end{tabular}

Descriptive findings and analysis:

Table III: Gender

\begin{tabular}{|c|c|c|}
\hline & Frequency & Percentage \\
\hline \multicolumn{3}{|l|}{ Gender } \\
\hline Male & 203 & 48.8 \\
\hline Female & 213 & 51.2 \\
\hline
\end{tabular}

Table III: Age

\begin{tabular}{|c|c|c|}
\hline Age & Frequency & Percentage \\
\hline 18-24 Years & 74 & 17.8 \\
\hline 25-34 Years & 150 & 36.1 \\
\hline 35-44 Years & 120 & 28.8 \\
\hline 45-54 Years & 57 & 13.7 \\
\hline 55-64 Years & 15 & 3.6 \\
\hline
\end{tabular}

Out of the 416 Jordanian e-Bank application users, a small majority (51.2\%) were male users, and the rest $(48.8 \%)$ were female. The respondents were all adults and their age ranged between 18 and 64 years or older, but of them (17.8\%) were aged between (18-24 years), another (36.1\%) were aged between (25-34 Years), also another ( $28.8 \%$ ) of them were aged between (35-44 Years), also a few of them (13.7\%) were aged between (45-54 Years) and even fewer (3.6\%) were aged between (55-66 or more Years).

Table IV: Regression Analysis

\begin{tabular}{|c|c|c|c|c|c|c|c|c|}
\hline & & & & $\begin{array}{r}95 \% \\
\text { Inte }\end{array}$ & $\begin{array}{l}\text { dence } \\
\text { or B }\end{array}$ & $\begin{array}{c}\text { t- } \\
\text { value }\end{array}$ & p & $\begin{array}{c}\text { Model } \\
\mathbf{R}^{\wedge} 2\end{array}$ \\
\hline & B & $\begin{array}{l}\text { Std. } \\
\text { Err. }\end{array}$ & $\begin{array}{c}\text { Standardized } \\
\text { Beta }\end{array}$ & $\begin{array}{l}\text { Lower } \\
\text { Bound }\end{array}$ & $\begin{array}{l}\text { Upper } \\
\text { Bound }\end{array}$ & & & \\
\hline (Constant) & & .045 & & -.089 & .089 & .000 & 1.000 & 0.149 \\
\hline $\begin{array}{l}\text { Security } \\
\text { risk }\end{array}$ & .386 & .045 & .386 & .297 & .475 & 8.507 & .000 & \\
\hline
\end{tabular}


Moreover, we priori hypothesized that the usage will be negatively associated security risk. As such, we computed a standardized score ( $\mathrm{Z}$ score) for both variables and tested them using simple linear regression technique. The model suggested that a significant relationship between mobile banking users perceived security risk and their overall rate ( i.e., frequency ) using the mobile applications, $f(1,415)=72.4, p<0.001$ also the model suggested that the standardized security score accounted for at least $38.9 \%$ of the variations in the rate of using the mobile banking applications, the adjusted R-squared however was less, denoting that only ( $\mathrm{r}$ squared $=14.9 \%$ ) of the variations in using the mobile banking was explained by the mobile banking users sense of security.

This denotes that greater mobile banking users perceptions of security with mobile banking was significantly, $\mathrm{t}$-value $=8.51, \mathrm{p}<0.001$, associated with less rate of using the mobile banking applications, and vice versa. In simple words, as predicted greater security risk was associated with greater reported use of the mobile banking applications among Jordanian mobile banking users and in the same like less sense of security of mobile banking networks was associated with less rate of using the mobile banking applications, as such. Other qualitative data help in deeper understanding of the factors that influence the adoption of mobile banking in Jordan, some of the new ideas and constructs are suggested by the respondents such as: Main obstacles fond during the use of Mbanking from the perspective of customers:

In addition to the common and main factors that mentioned before, the qualitative data provided to the researcher with some of suggested factors and ideas that influence the adoption of m-banking services in Jordan which will help in this research and the future research and need to be discussed and addressed in more details. The customers suggested that factors of: Trust, mobile network, Small screen size, Iinternet speed, Identity authentication, Security and accuracy, phone's battery life and clear screen.

\section{Conclusion}

In this paper, after distributing a brief survey to a number of mobile banking apps users through the social media and other electronic channels, which creates clearer understanding of the current status of the usage of mobile banking by Jordanians. I have discussed some issues and factors that related to mobile banking adoption in the Jordanian context, examine issues on the architecture as well as some security measures to deal with the related current challenges. I found that mobile banking services need to have a foundation to enhance the performance of the apps and the trust of customers, security and support future technologies. This ensures that mobile apps and their security framework remains future-proof and requires fewer resources to manage longterm.

\section{References}

[1] Barnes, S. \& Corbitt, B. (2003). Mobile banking: concept and potential. International Journal Of Mobile Communications, 1(3), 273. http://dx.doi.org/10.1504/ijmc.2003.003494

[2] Capgemini , EMA Empowers Employees with Anytime Anywhere Access to its Unique Portal | Resource. (2015). Capgemini Capgemini Worldwide. Retrieved 15 February 2016, from https://www.capgemini.com/resources/

[3] Data and Research on Digital for Business Professionals | eMarketer. (2014). Emarketer.com. Retrieved 15 August 2015, from http://www.eMarketer.com

[4] Laforet, S., \& Li, X. (2005). Consumers' attitudes towards online and mobile banking in China. International Journal of Bank Marketing. doi:10.1108/02652320510629250

[5] Zhou, T. (2012). Understanding users' initial trust in mobile banking: An elaboration likelihood perspective. Computers In Human Behavior, 28(4), 1518-1525. http://dx.doi.org/10.1016/j.chb.2012.03.021

[6] Riquelme, H. E., \& Rios, R. E. (2010). The moderating effect of gender in the adoption of mobile banking. International Journal of Bank Marketing. doi:10.1108/02652321011064872

[7] Rahmani, F. (2008). A Call for Innovation. IEEE Pervasive Computing, 7(1). http://dx.doi.org/10.1109/MPRV.2008.2. 
[8] Al-Qirim, N. (2007). The Adoption and Diffusion of E-Commerce in Developing Countries: The Case of an NGO in Jordan. Information Technology for Development, 13(2), 107-131. doi:10.1002/itdj.20053 Retrieved from http://www.interscience.wiley.com

[9] Luarn, P. \& Lin, H. (2005). Toward an understanding of the behavioral intention to use mobile banking. Computers In Human Behavior, 21(6), 873-891. http://dx.doi.org/10.1016/j.chb.2004.03.003[10] Akturan, U., \& Tezcan, N. (2012). Mobile banking adoption of the youth market. Marketing Intelligence \& Planning, 30(4), 444-459. http://dx.doi.org/10.1108/02634501211231928

[10] Cavus, N., \& Christina, D. (2016). Information technology in the banking sector: Review of mobile banking. Global Journal Of Information Technology, 5(2), 62. http://dx.doi.org/10.18844/gjit.v5i2.196

[11]Gu, J., Lee, S., \& Suh, Y. (2009). Determinants of behavioral intention to mobile banking.Expert Systems With Applications, 36(9), 11605-11616. http://dx.doi.org/10.1016/j.eswa.2009.03.024

[12] MHA, K. (2015). A Mobile Banking Adoption Model in the Jordanian Market: An Integration of TAM with Perceived Risks and Perceived Benefits. J Internet Bank Commer, 20(3). http://dx.doi.org/10.4172/1204-5357.1000128

[13] Ajzen, I. (1991). The theory of planned behavior. Organizational Behavior and Human Decision Processes, 50(2), 179219.

[14] Ajzen, I., \&Fishbein,, M. (1980). Understanding attitudes and predicting social behavior. (1st ed.). Englewood Cliffs, USA: Prentice Hall.

[15]Davis, F. (1989). Perceived Usefulness, Perceived Ease of Use, and User Acceptance of Information Technology. MIS Quarterly, 13(3), 319. http://dx.doi.org/10.2307/249008

[16] Miller, K., Deci, E., \& Ryan, R. (1988). Intrinsic Motivation and Self-Determination in Human Behavior. Contemporary Sociology, 17(2), 253. http://dx.doi.org/10.2307/2070638

[17] Taylor, S. \& Todd, P. (1995). Understanding Information Technology Usage: A Test of Competing Models. Information Systems Research, 6(2), 144-176. http://dx.doi.org/10.1287/isre.6.2.144

[18] Triandis, H. (1979). Values, Attitudes, and Interpersonal Behaviour. Nebraska Symposium on Motivation, 27, 195-259.

[19] Rogers, E. M. (2003). Diffusion of innovations . (5th ed.). New york, USA: Free press.

[20] Blackwell, G. (1942). Social Learning and Imitation. By Neal E. Miller and John Dollard. New Haven: Yale University Press, 1941. 341pp. Social Forces, 21(2), 256-256. http://dx.doi.org/10.2307/2570586

[21] Venkatesh, V., Morris, M. G., Davis, G. B., \& Davis, F. D. (2003). User Acceptance of Information Technology: Toward a Unified View. Management Information Systems Quarterly.

[22] Bryman, A., \& Bell, E. (2011). Business research methods. (3rd ed.). New York, USA: OxfordUniversity press Inc.

[23] Bhaskar, R. A. (1989). A Critical Introduction to Contemporary Philosophy. In Reclaiming Reality. London, UK: Verso

[24] Yin, R. (2009). Case study research. Los Angeles, Calif.: Sage Publications.

[25] Bhattacherjee, A. (2012). Social science research: Principles, methods, and practices. (2nd Ed.). Florida, USA:

AnolBhattacherjee.

[26] Nunnally, J. C. (1978). Psychometric theory. New York, NY: McGraw-Hill

[27] Huang, D.L., P. L.P. Rau and G. Salvendy, 2010. Perception of information security.

[28] Al-Tarawneh, J. (2016). Factors influencing the adoption of Mobile banking services in Jordan from the perspective of customers: Overview and Pilot study. International Journal Of Scientific And Research Publications, 6(9), 207-2013. 